\title{
(C) OPEN ACCESS \\ Fiducial marker implantation using convex probe EBUS and autologous blood
}

\author{
Justin L Garner, Ines Meireles, Samuel V Kemp, Pallav L Shah
}

Respiratory Medicine, Royal Brompton and Harefield NHS Foundation Trust, London, UK

\section{Correspondence to} Dr Justin L Garner, j.garner@rbht.nhs.uk

Accepted 5 March 2019

\section{DESCRIPTION}

Stereotactic body radiotherapy (SBRT) has evolved as an improved treatment strategy for early-stage lung cancer in individuals who are unfit for surgery ${ }^{1}$ and for oligometastatic disease. ${ }^{2}$ Precision targeting of small lesions for high-dose radiation is key. This is frequently facilitated with intralesional placement of radio-opaque fiducial markers (FMs) to guide the therapist. $^{3}$

There are a number of bronchoscopic techniques reported which deliver the device in a hollow needle, encouraged to remain in place with, for example, sterile bone wax $^{4}$ or surgical lubricant, ${ }^{5}$ until expelled into the channel bored in the lesion.

Here, we suggest what we believe to be a beneficial modification, using the universally available autologous blood as glue to secure the device in the dedicated Endobronchial Ultrasound (EBUS) needle during its deployment.

A 67-year-old woman with metastatic colorectal carcinoma (hepatic and pulmonary) was referred to our bronchoscopic service for placement of an FM in a chest lesion prior to SBRT.
Under deep sedation, a convex-probe EBUS bronchoscope (BF-UC260FW; Olympus) was navigated to a right paratracheal mass. A dedicated 19-gauge EBUS needle was introduced into the working channel and a transbronchial needle aspiration was performed under ultrasound guidance to create a tunnel into the lesion.

The needle was then removed from the bronchoscope, the stylet partially retracted and a $0.9 \times 13 \mathrm{~mm}$ gold FlexiMarc ${ }^{\mathrm{TM}} \mathrm{FM}$ introduced to the distal end of the flex needle, front-loaded and sealed with a drop of blood freshly taken from the patient into a syringe without anticoagulant (figure 1).

The loaded needle, in its protective sheath, was reintroduced into the bronchoscope and advanced to the orifice of the track. Using real-time ultrasound, the needle was progressed to the centre of the mass and the stylet deployed to expel the FM.

The procedure was planned to avoid delay and ensure the track remained navigable.

A chest X-ray following bronchoscopy confirmed satisfactory placement and excluded

\section{Check for updates}

(c) BMJ Publishing Group Limited 2019. Re-use permitted under CC BY-NC. No commercial re-use. See rights and permissions. Published by BMJ.

To cite: Garner JL, Meireles I, Kemp SV, et al. BMJ Case Rep 2019;12:e228773. doi:10.1136/bcr-2018228773

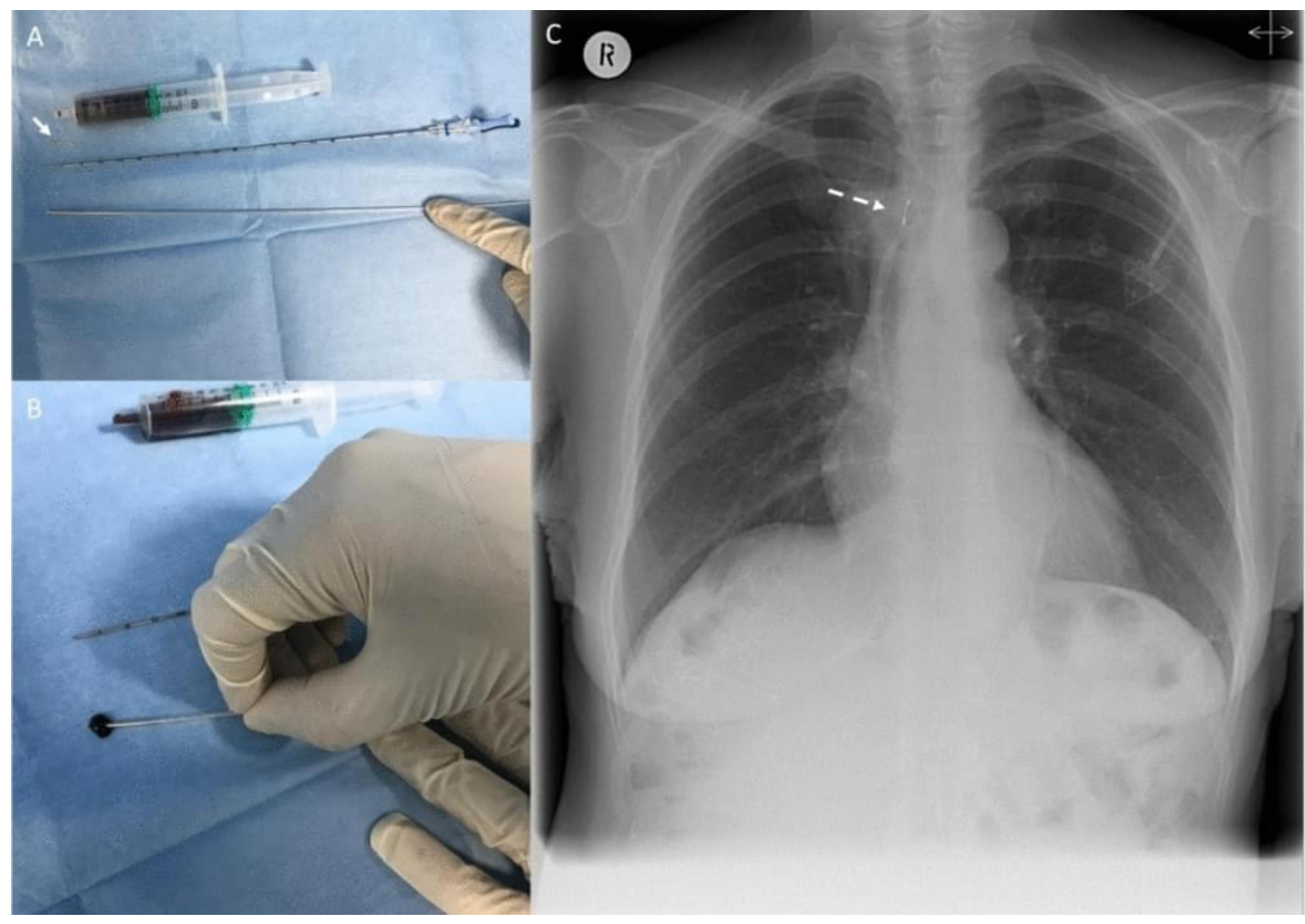

Figure 1 (A) From top to bottom, syringe of autologous blood, gold fiducial marker (FM; arrow), percutaneous delivery needle and 19-gauge EBUS needle (Olympus). (B) Sealing FM in distal end of EBUS needle using autologous blood. (C) Postprocedure chest X-ray showing deployed FM in the right paratracheal mass (dashed arrow). 


\section{Learning points}

- Convex probe EBUS-guided placement of fiducial markers (FMs) is an established procedure to facilitate the precise targeting of intrathoracic masses of interest to radiotherapists.

- We report a modification to the FM implantation technique, using readily available autologous blood as the agent to secure an FM in its delivery EBUS needle, obviating the requirement for commercial foreign materials: inexpensive and unlikely to be a source of harm.

- This is a quick and straight-forward technique to supplement Convex-probe Endobronchial Ultrasound (cEBUS)-guided mediastinal diagnosis and staging, and when combined with rapid on-site evaluation of cytology, can be performed in one procedural sitting.

a pneumothorax. The patient underwent successful SBRT and required no further FM installations.

Lee reported in addition to haemorrhage and pneumothorax complicating percutaneous procedures, a case of migration of a successfully placed FM into an airway after injection of a blood patch. ${ }^{6}$ Our approach uses a transbronchial route, and we use the autologous blood ex vivo to secure the fiducial onto the needle rather than injecting autologous blood into the patient.

Contributors $J L G$ is the guarantor of the content of the manuscript. JLG, IM and PLS performed the procedure. JLG, IM, SVK and PLS conceived the article. JLG produced the first draft of the manuscript and IM, SVK and PLS made subsequent revisions. All of the authors meet the definition of an author as stated by the International Committee of Medical Journal Editors, and all have seen and approved the final manuscript.

Funding The authors have not declared a specific grant for this research from any funding agency in the public, commercial or not-for-profit sectors.

Competing interests None declared.

Patient consent for publication Obtained.

Provenance and peer review Not commissioned; externally peer reviewed.

Open access This is an open access article distributed in accordance with the Creative Commons Attribution Non Commercial (CC BY-NC 4.0) license, which permits others to distribute, remix, adapt, build upon this work non-commercially, and license their derivative works on different terms, provided the original work is properly cited and the use is non-commercial. See: http://creativecommons.org/ licenses/by-nc/4.0/

\section{REFERENCES}

1 Chua KLM, Sin I, Fong KW, et al. Stereotactic body radiotherapy for early stage lung cancer-historical developments and future strategies. Chin Clin Oncol 2017:6:S20.

2 Kennedy TAC, Corkum MT, Louie AV. Stereotactic radiotherapy in oligometastatic cancer. Chin Clin Oncol 2017:6(Suppl 2):S16.

3 Jackson P, Steinfort DP, Kron T, et al. Practical assessment of bronchoscopically inserted fiducial markers for image guidance in stereotactic lung radiotherapy. J Thorac Oncol 2016:11:1363-8.

4 Majid A, Palkar A, Kheir F, et al. Convex Probe EBUS-guided fiducial placement for malignant central lung lesions. J Bronchology Interv Pulmonol 2018;25:283-9.

5 Belanger AR, Zagar T, Akulian JA. Convex endobronchial ultrasound-guided fiducial placement for malignant central lung lesions: a case series. J Bronchology Interv Pulmonol 2016;23:46-50.

6 Lee C. Airway migration of lung fiducial marker after autologous blood-patch injection. Cardiovasc Intervent Radiol 2012;35:711-3.

Copyright 2019 BMJ Publishing Group. All rights reserved. For permission to reuse any of this content visit https://www.bmj.com/company/products-services/rights-and-licensing/permissions/

BMJ Case Report Fellows may re-use this article for personal use and teaching without any further permission.

Become a Fellow of BMJ Case Reports today and you can:

- Submit as many cases as you like

- Enjoy fast sympathetic peer review and rapid publication of accepted articles

- Access all the published articles

- Re-use any of the published material for personal use and teaching without further permission

For information on Institutional Fellowships contact consortiasales@bmjgroup.com

Visit casereports.bmj.com for more articles like this and to become a Fellow 